\title{
THE STUDY OF THE ANTECEDENTS OF RETAIL SHOPPERS' REPATRONAGE INTENTIONS: AN EMPIRICAL STUDY
}

\author{
Andreas Widjaja and Budi Hartono Kusuma \\ Management Department, Business School, University Pelita Harapan \\ Email: budi.kusuma@uph.edu
}

\begin{abstract}
One of important factors that determine the success of retail stores is how to make customers go to shop there, in which they have to shop there continuously. So, retailers should have to satisfy customers in order to keep customers. In this research, the researcher would like to test and describe customer satisfaction and repatronage intentions, through eight variables in Carrefour and Hypermart, and developed into seven hypotheses. This research uses 160 samples to ask their perceptions about Carrefour and Hypermart. Then, from that research, there are two hypotheses that are rejected and five hypotheses that are accepted. Perceived product quality and perceived price are considered as insignificant antecedents of customer satisfaction. However, perceived service quality, store assortment, trust and commitment are considered as significant antecedents of customers' satisfaction, and customer satisfaction is significant antecedent of repatronage intentions.
\end{abstract}

Keywords: Marketing, Consumer Behavior, Perceived Product Quality, Percieved Service Quality, Store Assortment, Perceived Price/Price Perceptions, Trust, Commitment, Customer Satisfaction, Repatronage Intentions.

Abstrak: Salah satu faktor penting yang menentukan keberhasilan toko ritel adalah bagaimana membuat pelanggan pergi untuk berbelanja di sana, di mana mereka harus berbelanja di sana terus. Jadi, pengecer harus memiliki untuk memuaskan pelanggan untuk mempertahankan pelanggan. Dalam penelitian ini, peneliti ingin menguji dan menjelaskan kepuasan pelanggan dan repatronage niat, melalui delapan variabel di Carrefour dan Hypermart, dan berkembang menjadi tujuh hipotesis. Penelitian ini menggunakan 160 sampel untuk meminta persepsi mereka tentang Carrefour dan Hypermart. Kemudian, dari penelitian itu, ada dua hipotesis yang ditolak dan lima hipotesis yang diterima. Persepsi kualitas produk dan harga yang dirasakan dianggap sebagai anteseden penting dari kepuasan pelanggan. Namun, kualitas pelayanan yang dirasakan, toko bermacam-macam, kepercayaan dan komitmen dianggap sebagai anteseden yang signifikan dari kepuasan pelanggan, dan kepuasan pelanggan adalah yg signifikan dari niat repatronage.

Kata kunci: Pemasaran, Perilaku Konsumen, Persepsi Kualitas Produk, percieved Service Quality, Toko Assortment, Perceived Persepsi Harga / Harga, Trust, Komitmen, Kepuasan Pelanggan, Intentions Repatronage.

\section{INTRODUCTION}

In the $20^{\text {th }}$ century, the need of satellite cities are increased rapidly, in which located in adjacent with the big city (Merrilees et al., 2013). In Jabodetabek area, one of these satellite cities is Lippo Karawaci. Lippo Karawaci is facilitated with educational institutions, businesses, and other facilities. One of these businesses is hypermarket, 
fulfilling needs and wants of people live in Lippo Karawaci. These hypermarkets are Hypermart and Carrefour, in which both of them are located in Supermall Karawaci. Carrefour is owned by CT Group, and operates 85 stores according to its official website. Besides, there is Hypermart, which is owned by Matahari Putra Prima, and according to its financial report, Hypermart operates more than 99 stores across Indonesia.

Shoppers' satisfactions and repatronage intentions are becoming current major concerns in this research. Repatronage intentions refer to how likely a shopper will shop continuously in a retail store (Akbar, 2014). Retailers should pay attention to customer satisfaction that brings positive impact to their profit. Retailers should do their best to satisfy customers' needs and wants. Therefore, it is not easy to come up with an instant way, which will make the shoppers happy easily (Akbar, 2014). In this research, the author will replicate research that is conducted before by Akbar (2014) in Bangladesh. This study is replicated and adapted for Hypermart and Carrefour in Supermall Karawaci.

\section{METHODS}

Hypothesis Development. Perceived Service Qualit. Service Quality is defined as customers' long term, cognitive evaluations of a firm's service delivery (Lovelock and Writz, 2011). Customers will compare what they have been expected before, and what they have experienced during the service delivery, and it can influence customers' satisfaction. When the retailers can provide good service quality, customers can be more satisfied. When the retailers fail in providing good service quality, customers can be more dissatisfied. Therefore, this hypothesis is developed

$\mathrm{H}_{1}$ - Perceived service quality has positive impact on customer satisfaction.

Perceived Product Quality. Product Quality is defined as the consumers' judgment about a product's overall excellence and superiority (Tsiotsou, 2006). After purchasing and usage, customers evaluate whether they are satisfied with the product of not. Like service, customer has certain expectation on product, and it can influence the satisfaction of the shoppers. Both service and product quality can influence customer satisfaction. Therefore, this hypothesis is developed $\mathrm{H}_{2}$ - Perceived product quality has positive impact on customer satisfaction.

Store Assortment. An important issue of managing store is store assortment, in retailers should offer an opportunity to visit a retail store at one stop shopping and purchasing goods and services there (Chaiyasoonthorn and Suksa-ngiam, 2011). Without stopping at other stores, customers can get goods and services that are needed at one stop shopping. Therefore, the variety of the product can influence satisfaction level of customers (Huddleston et al., 2011). From these statements, this hypothesis is proposed

$\mathrm{H}_{3}$ - Store assortment has positive impact on customer satisfaction.

Perceived Price. Perceived price is defined as notion whether the customers consider a product's price as high, low, or fair (Schiffman and Kanuk, 2007). Several people feel that the price can be fair or unfair. If customers find that the price that they pay is considered by customers as unfair, therefore they may be disappointed with the 
store. On the other hand, if customers find that the price that they pay is considered by customers as unfair, therefore they may be disappointed with the store. Therefore, this following hypothesis is proposed

$\mathrm{H}_{4}$ - Perceived price has positive and significant impact on customer satisfaction.

Trust. Trust is applied in people's life, including in retailing business. Trust itself is defined as willingness to rely on exchange partner in whom a party has confidence (Lo, 2013). In order to show trust, retailers' personnel must deliver high level of any kind of relationship (Akbar, 2014). Retailers should be able to show trustworthiness to their customers. By showing trustworthiness, customers can trust the organization, which will lead to customer satisfaction (Deng et al., 2010). Therefore, it is hypothesized that $\mathrm{H}_{5}$ - Trust has positive on customer satisfaction

Commitment. Schiffman et al. (2008), defined commitment in marketing literature as strength of a consumer relationship to brand, service, or a product. Committed customers tend to be loyal, has a certain emotional feeling towards the brand (Hawkins and Motherbaugh, 2010). They are willing to use the same brand, since they have certain emotional attachment. Customers are committed to the brand because of their satisfaction. Therefore, it is hypothesized that

$\mathrm{H}_{6}$ - Commitment has positive impact on customer satisfaction

Customer Satisfaction. Customer Satisfaction is defined as customers' perception of performance of the product or service in relation to his or her expectations (Schiffman and Kanuk, 2007). In order to maintain profit, retailers should be able to keep their shoppers happy, by fulfilling customers' expectations for the retailers. Customers measures whether the retailers can fulfill customers' expectations well. If not, customers tend to show dissatisfaction.

Repatronage Intentions. Repatronage intentions refer to notion that how likely a shopper will continue shopping at the same retail store in the future (Akbar, 2014). According to Akbar (2014), shoppers' repatronage intentions are known as revisit intention, continuance intention, and also customer retention. According to Akbar (2014) and several other researchers, there are several antecedents of repatronage intentions and one of them is Customer Satisfaction. Therefore, it is hypothesized that $\mathrm{H}_{7}$ - Customer Satisfaction has positive on Repatronage Intentions.

Research Model. Akbar (2014) in his previous research uses the following research model in several retail stores in Bangladesh. In this research, this model is used in two major retail stores in Supermall Karawaci.

Sampling. For this research, the sampling technique that is used is simple random sampling, in which are most widely used in quantitative research (McDaniels and Gates, 2010). In simple random sampling, each element in the population has definite and same probability of selection (Malhotra, 2007). Then, sample size of this research is 160 samples, obtained by multiplying total measures into five or ten (Hair et al., 2010). 


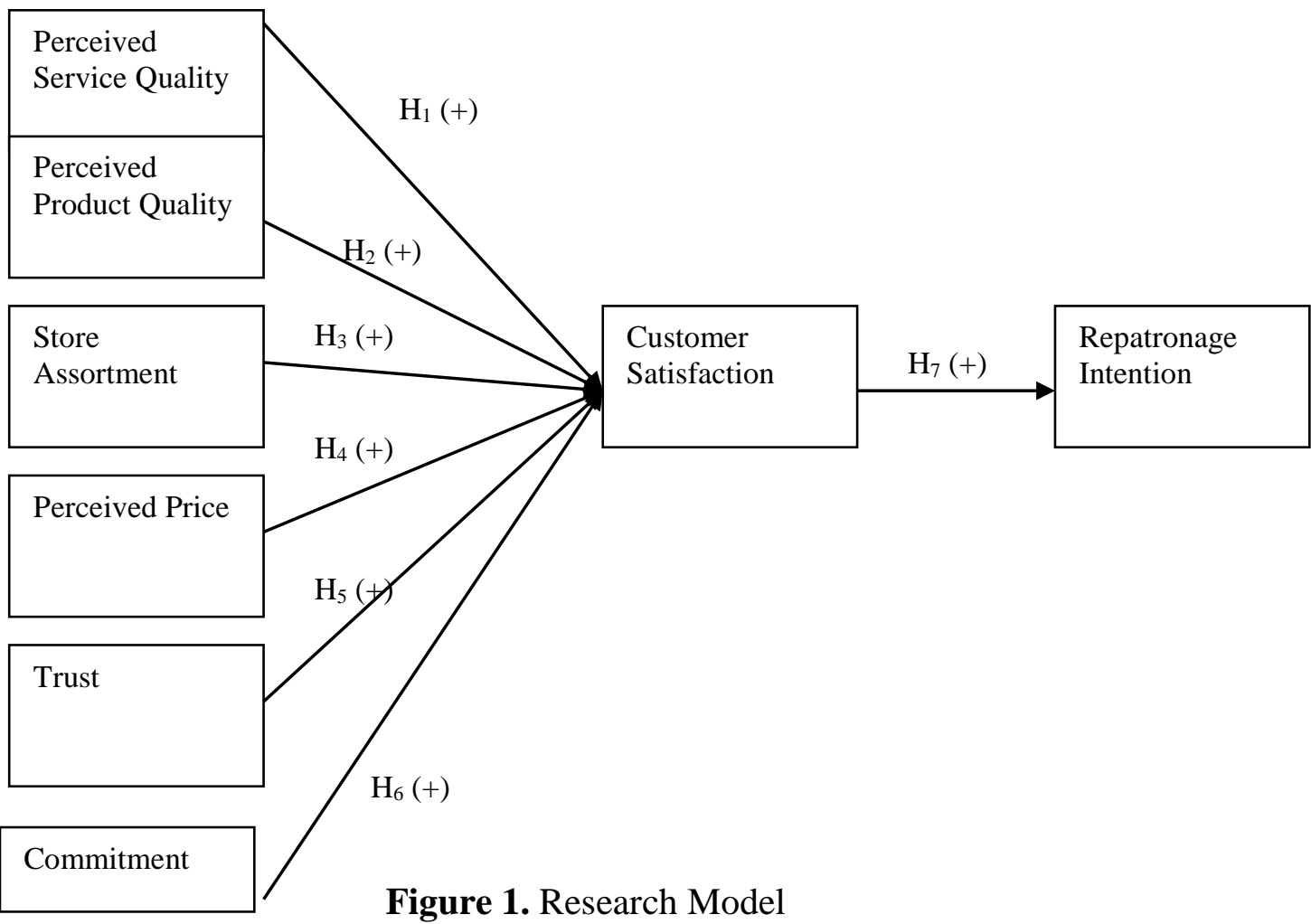

\section{Measurement Instruments}

The questionnaire consists of 32 questions, in which each variable has four questions. Table 1 . below shows the questionnaire items and its source.

Table 1. List of Questionnaire questions

\begin{tabular}{|c|c|c|c|}
\hline Variable & Operational Definition & Scale & Source \\
\hline $\begin{array}{l}\text { Perceived Service } \\
\text { Quality (PSQ) }\end{array}$ & $\begin{array}{l}\text { 1. In terms of service delivery, my } \\
\text { preferred hypermarket has an } \\
\text { excellent overall service. } \\
\text { 2. In terms of service delivery, my } \\
\text { preferred hypermarket has a } \\
\text { service of very high quality } \\
\text { 3. In terms of service delivery, } \\
\text { my preferred hypermarket } \\
\text { provides a high standard of } \\
\text { service } \\
\text { 4. Employees of my preferred } \\
\text { hypermarket are always willing to } \\
\text { help me when needed } \\
\text { 1. My preferred hypermarket has } \\
\text { good quality merchandise } \\
\text { 2. I shop in my preferred } \\
\text { hypermarket because its } \\
\text { products are superior to its }\end{array}$ & $\begin{array}{l}1-7 \\
\text { likert } \\
\text { scale }\end{array}$ & $\begin{array}{l}\text { Yang and Chang, } \\
2012 \\
\text { Huddleston et al., } \\
2008\end{array}$ \\
\hline
\end{tabular}


Perceived Product Quality (PPQ) competitor

3. The product at my preferred 1-7 hypermarket are of high quality likert

4. The products at my preferred scale hypermarket are very satisfactory compared to others

Table 1. List of Questionnaire questions (Continued)

\begin{tabular}{|c|c|c|c|}
\hline Variable & Operational Definition & Scale & Source \\
\hline \multirow[t]{2}{*}{$\begin{array}{c}\text { Store } \\
\text { Assortment } \\
\text { (SA) }\end{array}$} & $\begin{array}{l}\text { 1. I think that my preferred } \\
\text { hypermarket sells a wide range of } \\
\text { products } \\
\text { 2. I can compare a lot of products in } \\
\text { my preferred hypermarket } \\
\text { 3. Only one visit, I can get all } \\
\text { products which I want in my } \\
\text { preferred hypermarket } \\
\text { 4. My preferred hypermarket has an } \\
\text { extensive assortment of products }\end{array}$ & $\begin{array}{l}1-7 \\
\text { likert } \\
\text { scale }\end{array}$ & $\begin{array}{c}\text { Chaiyasoonthorn } \\
\text { and Suksa-ngiam, } \\
2011\end{array}$ \\
\hline & & & $\begin{array}{l}\text { Huddleston et al., } \\
2008\end{array}$ \\
\hline $\begin{array}{c}\text { Price } \\
\text { Perception } \\
\text { (PP) }\end{array}$ & $\begin{array}{l}\text { 1. I think the price labels in my } \\
\text { preferred hypermarket are } \\
\text { cheap } \\
\text { 2. I have received a large discount } \\
\text { from my preferred hypermarket } \\
\text { 3. I have received gifts/gifts } \\
\text { vouchers from my preferred } \\
\text { hypermarket } \\
\text { 4. I will probably save more money } \\
\text { when I buy goods in my preferred } \\
\text { hypermarket }\end{array}$ & $\begin{array}{l}1-7 \\
\text { likert } \\
\text { scale }\end{array}$ & $\begin{array}{c}\text { Chaiyasoonthorn } \\
\text { and Suksa-ngiam, } \\
2011\end{array}$ \\
\hline $\begin{array}{l}\text { Trust } \\
\text { (TR) }\end{array}$ & $\begin{array}{l}\text { 1. The employees of that } \\
\text { hypermarket can be trusted all } \\
\text { times } \\
\text { 2. My preferred hypermarket is } \\
\text { trustworthy } \\
\text { 3. My preferred hypermarket } \\
\text { keeps its promises and } \\
\text { commitments } \\
\text { 4. My preferred hypermarket } \\
\text { cares about its customers }\end{array}$ & $\begin{array}{l}1-7 \\
\text { likert } \\
\text { scale }\end{array}$ & $\begin{array}{l}\text { Wong and Sohal, } \\
2006 \\
\text { Kim et al., } 2011\end{array}$ \\
\hline
\end{tabular}




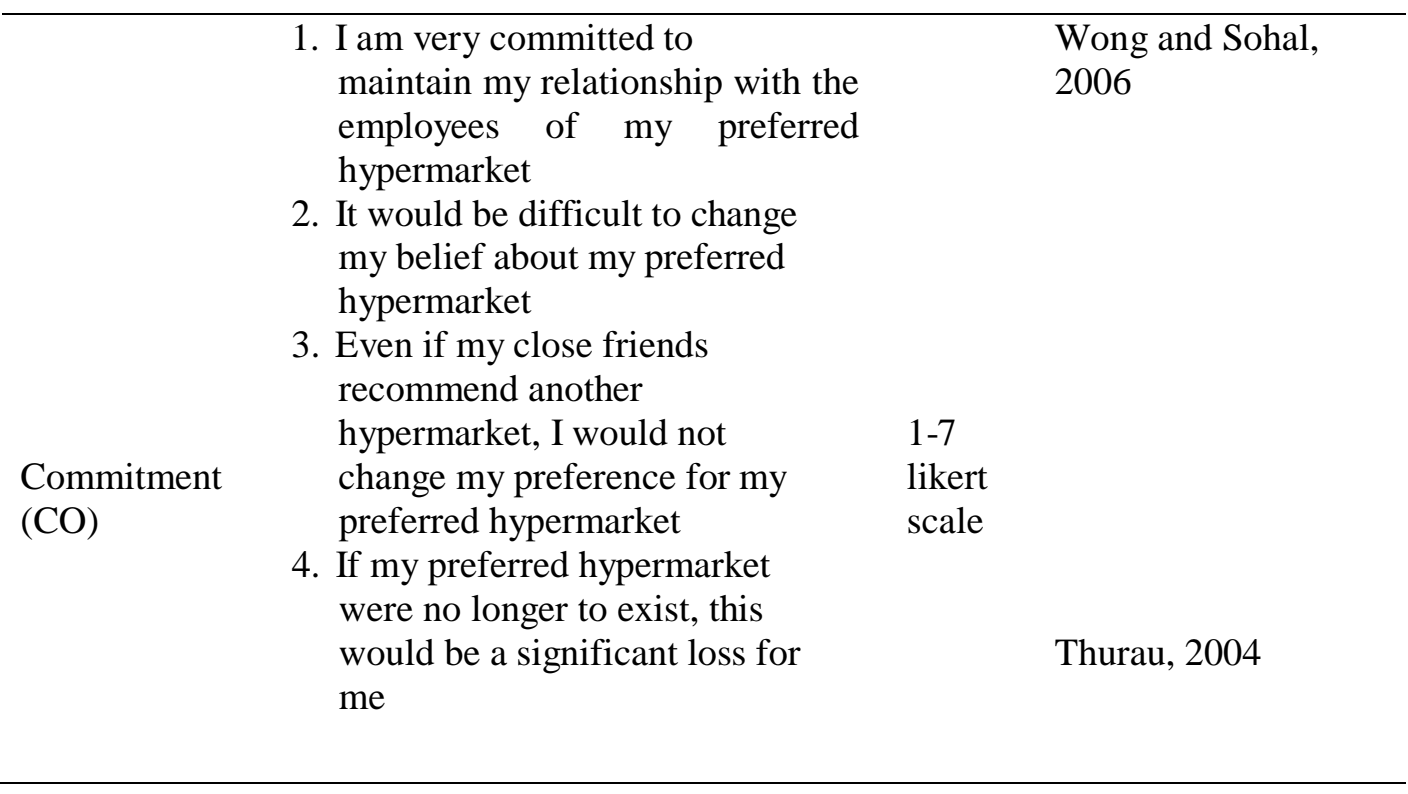

Table 1. List of Questionnaire questions (Continued)

\begin{tabular}{|c|c|c|c|}
\hline \multicolumn{2}{|c|}{ Variable Operational Definition } & \multicolumn{2}{|l|}{ Source } \\
\hline $\begin{array}{l}\text { Customer } \\
\text { Satisfaction } \\
\text { (CS) }\end{array}$ & $\begin{array}{l}\text { 1. I am very satisfied with the } \\
\text { service provided in my } \\
\text { preferred store } \\
\text { 2. It is a satisfying experience for } \\
\text { me to use my preferred } \\
\text { hypermarket } \\
\text { 3. Compared to other hypermarket, I } \\
\text { am very satisfied with this } \\
\text { hypermarket } \\
\text { 4. In general, I am satisfied with } \\
\text { my preferred hypermarket }\end{array}$ & $\begin{array}{l}1-7 \\
\text { likert } \\
\text { scale }\end{array}$ & $\begin{array}{l}\text { Yang and Chang, } \\
2011\end{array}$ \\
\hline $\begin{array}{l}\text { Repatronage } \\
\text { Intention (RI) }\end{array}$ & $\begin{array}{l}\text { 1. I will probably use my } \\
\text { preferred hypermarket in the } \\
\text { future } \\
\text { 2. My preferred hypermarket is } \\
\text { my first choice when I go } \\
\text { shopping } \\
\text { 3. I am glad to recommend my } \\
\text { preferred hypermarket to my } \\
\text { friends } \\
\text { 4. I will recommend my preferred } \\
\text { hypermarket when someone } \\
\text { asking my suggestion }\end{array}$ & $\begin{array}{l}1-7 \\
\text { likert } \\
\text { scale }\end{array}$ & $\begin{array}{l}\text { Yang and Chang, } \\
2011\end{array}$ \\
\hline
\end{tabular}

Source: Processed data, 2014 
Data Analysis. The data are processed by using SPSS and SEM-PLS. SPSS is used to obtain the descriptive statistics that can be used in helping the data analysis, such as frequencies, mean, and standard deviation. Then, SEM-PLS is used to measure the validity, reliability, and the hypotheses testing.

In order to measure validity, Factor Loading of each question should be above 0.5 or higher, Average Variance Extracted should be above 0.5 or higher, and square-root of AVE should be higher than correlations between each constructs (Hair et al., 2006). Meanwhile, reliability is measured by using Construct Reliability, in which has value more than 0.6. Reliability cannot be established when Construct Reliability has value less than 0.6. Lastly, a hypothesis is accepted and supported if it has t-statistics more than 1.64 for one-tail hypothesis (Hartono, 2011). For hypothesis testing, the samples are bootstrapped in order to gain more representative sample. The samples are bootstrapped into 5,000 samples.

\section{RESULT AND DISCUSSION}

Table 2 below shows the frequency of respondents' profile.

Table 2. Actual Test Respondents’ profile

\begin{tabular}{lll}
\hline Profile & Respondents & Percentage \\
\hline Gender & Male & $38.8 \%$ \\
Age & Female & $61.2 \%$ \\
& $<17$ & $0 \%$ \\
& $17-20$ & $49.4 \%$ \\
& $21-24$ & $39.4 \%$ \\
& $25-28$ & $3.1 \%$ \\
Place & $>28$ & $8.1 \%$ \\
Frequency each month & Hypermart & $57.5 \%$ \\
& Carrefour & $42.5 \%$ \\
& 1 time & $14.4 \%$ \\
Expenditure each month & $2-4$ times & $58.1 \%$ \\
& $5-7$ times & $12.5 \%$ \\
& $>7$ times & $15 \%$ \\
& $<200,000$ & $38.1 \%$ \\
& $200,000-500,000$ & $43.1 \%$ \\
Marital Status & $500,001-1,000,000$ & $13.1 \%$ \\
& $>1,000,000$ & $5.6 \%$ \\
Occupation & Single & $92.5 \%$ \\
& Married & $7.5 \%$ \\
& Students & $83.1 \%$ \\
& Housewives Private & $1.3 \%$ \\
& Employees Civil & $11.9 \%$ \\
& Servants & $0.6 \%$ \\
& Entrepreneurs & $2.5 \%$ \\
& Others & $0.6 \%$ \\
& &
\end{tabular}

Source: Processed Data, 2014 
From the table above, it is shown that most of the respondents are females, since most of them do groceries shopping. Most of respondents shop in Hypermart, and visit both hypermarkets 2-4 times monthly. Most of them spend 200,000-500,000 each month. Then, most of respondents are students, since the research mostly is taken in UPH.

Then, table 3 below shows the mean and standard deviation (central tendency and dispersion) of each indicator (questionnaire item). In the actual test, the researcher used only 30 questions, instead of all 32 answers due to invalidity of two questions.

Table 3. Mean and Standard Deviation on each Indicator

\begin{tabular}{lll}
\hline Item & Mean & Standard Deviation \\
\hline PSQ1 & 5.44 & 0.822 \\
PSQ2 & 5.09 & 0.967 \\
PSQ3 & 4.81 & 1.347 \\
PSQ4 & 5.23 & 1.093 \\
PPQ2 & 5.01 & 1.107 \\
PPQ3 & 5.04 & 0.977 \\
PPQ4 & 4.88 & 1.151 \\
SA1 & 5.09 & 1.302 \\
SA2 & 5.21 & 1.024 \\
SA3 & 5.32 & 1.101 \\
SA4 & 5.69 & 0.953 \\
PP1 & 4.69 & 1.298 \\
PP2 & 4.53 & 1.308 \\
PP3 & 4.12 & 1.442 \\
PP4 & 4.34 & 1.303 \\
TR1 & 4.86 & 1.021 \\
TR2 & 5.54 & 1.039 \\
TR3 & 4.70 & 1.069 \\
TR4 & 5.15 & 0.885 \\
CO1 & 4.35 & 1.260 \\
CO2 & 4.49 & 1.218 \\
CO3 & 4.30 & 1.448 \\
CS1 & 5.41 & 0.796 \\
CS2 & 5.22 & 0.949 \\
CS3 & 5.22 & 0.936 \\
CS4 & 5.44 & 1.186 \\
RI1 & 1.238 \\
RI2 & 4.44 & 1.178 \\
RI3 & 4.916 & \\
RI4 & & \\
\hline
\end{tabular}

Source: Processed Data, 2014 
It is shown in the table that most people are agree with question with coding SA4 (highest mean) and least people are agree with question with wording PP3 (lowest mean). However, most people have the same perception with question with coding CS1 (shown by the lowest standard deviation). On the other hand, most people tend to have diverse answers in the question with wording RI2 (highest standard deviation).

In table 4, the result of convergent validity test is shown below

Table 4. Actual Test Convergent Validity Result

\begin{tabular}{|c|c|c|c|c|}
\hline Variable & Indicator & Factor Loading & Valid/Invalid & AVE \\
\hline \multirow{4}{*}{ PSQ } & PSQ1 & 0.816 & VALID & \multirow{4}{*}{0.564} \\
\hline & PSQ2 & 0.843 & VALID & \\
\hline & PSQ3 & 0.579 & VALID & \\
\hline & PSQ4 & 0.739 & VALID & \\
\hline \multirow{3}{*}{ PPQ } & PPQ2 & 0.900 & VALID & \multirow{3}{*}{0.774} \\
\hline & PPQ3 & 0.893 & VALID & \\
\hline & PPQ4 & 0.845 & VALID & \\
\hline \multirow{4}{*}{ SA } & SA1 & 0.455 & INVALID & \multirow{4}{*}{0.592} \\
\hline & SA2 & 0.623 & VALID & \\
\hline & SA3 & 0.865 & VALID & \\
\hline & SA4 & 0.881 & VALID & \\
\hline \multirow{4}{*}{ PP } & PP1 & 0.635 & VALID & \multirow{4}{*}{0.542} \\
\hline & PP2 & 0.789 & VALID & \\
\hline & PP3 & 0.729 & VALID & \\
\hline & PP4 & 0.782 & VALID & \\
\hline \multirow{4}{*}{ TR } & TR1 & 0.765 & VALID & \multirow{4}{*}{0.563} \\
\hline & TR2 & 0.640 & VALID & \\
\hline & TR3 & 0.750 & VALID & \\
\hline & TR4 & 0.833 & VALID & \\
\hline \multirow{3}{*}{$\mathrm{CO}$} & CO1 & 0.859 & VALID & \multirow{3}{*}{0.681} \\
\hline & $\mathrm{CO} 2$ & 0.811 & VALID & \\
\hline & $\mathrm{CO} 3$ & 0.805 & VALID & \\
\hline \multirow{5}{*}{ CS } & CS1 & 0.805 & VALID & \multirow{5}{*}{0.600} \\
\hline & CS2 & 0.835 & VALID & \\
\hline & CS3 & 0.777 & VALID & \\
\hline & CS4 & 0.673 & VALID & \\
\hline & RI1 & 0.448 & INVALID & \\
\hline \multirow{3}{*}{ RI } & RI2 & 0.706 & VALID & \multirow{3}{*}{0.553} \\
\hline & RI3 & 0.880 & VALID & \\
\hline & RI4 & 0.860 & VALID & \\
\hline
\end{tabular}

Source: Processed Data (2014)

From the actual test, it is shown here that SA1 and RI1 has factor loading lower than 0.5 (considered as invalid). Therefore, in order to improve validity and reliability for this research, these two questions are removed. Then, discriminant validity is established. Table 5 below shows the discriminant validity table. 
Widjaja and Kusuma: The Study of The Antecedents of Retail Shoppers'...

Table 5. Discriminant Validity

\begin{tabular}{lllllllll}
\hline & PSQ & PPQ & SA & PP & TR & CO & CS & RI \\
\hline PSQ & $\mathbf{0 . 7 5 1}$ & & & & & & & \\
PPQ & 0.368 & $\mathbf{0 . 8 8 0}$ & & & & & & \\
SA & 0.388 & 0.341 & $\mathbf{0 . 7 6 9}$ & & & & & \\
PP & 0.228 & 0.311 & 0.408 & $\mathbf{0 . 7 3 6}$ & & & & \\
TR & 0.573 & 0.284 & 0.487 & 0.389 & $\mathbf{0 . 7 5 1}$ & & & \\
CO & 0.27 & 0.471 & 0.34 & 0.43 & 0.458 & $\mathbf{0 . 8 2 1}$ & & \\
CS & 0.619 & 0.489 & 0.554 & 0.35 & 0.594 & 0.562 & $\mathbf{0 . 7 7 3}$ & \\
RI & 0.432 & 0.432 & 0.436 & 0.41 & 0.381 & 0.494 & 0.651 & $\mathbf{0 . 8 4 1}$ \\
\hline
\end{tabular}

Source: Processed Data (2014)

After that, reliability can be established. Besides, it is improved when all invalid questions are removed. Table 6 below shows the reliability rate of each variable.

Table 6. Composite Reliability of Each Variable

\begin{tabular}{lllll}
\hline Variable & CR & Reliable/Not Reliable & Improved CR & Reliable/Not Reliable \\
\hline PSQ & 0.836 & RELIABLE & 0.836 & RELIABLE \\
PPQ & 0.911 & RELIABLE & 0.911 & RELIABLE \\
SA & 0.809 & RELIABLE & $\mathbf{0 . 8 6 0}$ & RELIABLE \\
PP & 0.825 & RELIABLE & 0.825 & RELIABLE \\
TR & 0.836 & RELIABLE & 0.836 & RELIABLE \\
CO & 0.865 & RELIABLE & 0.865 & RELIABLE \\
CS & 0.857 & RELIABLE & 0.857 & RELIABLE \\
RI & 0.824 & RELIABLE & $\mathbf{0 . 8 8 0}$ & RELIABLE \\
\hline
\end{tabular}

Source: Processed Data, 2014

It can be inferred that all the data that are gathered during the research are reliable, considered as accurate and consistent enough. Therefore, all variables and indicators can be used if they are valid enough. Then, all hypotheses are tested. Hypotheses result is presented in table 7. below.

Table 7. Result of Hypotheses Testing

\begin{tabular}{lrrrrrl}
\hline Hypotheses & $\begin{array}{l}\text { Original } \\
\text { Sample }\end{array}$ & $\begin{array}{l}\text { Sample } \\
\text { Mean }\end{array}$ & $\begin{array}{l}\text { Standard } \\
\text { Deviation }\end{array}$ & \multicolumn{1}{l}{$\begin{array}{l}\text { Standard } \\
\text { Error }\end{array}$} & $\begin{array}{l}\text { T- } \\
\text { Statistics }\end{array}$ & \multicolumn{1}{l}{$\begin{array}{l}\text { SUPPORTED/ } \\
\text { REJECTED }\end{array}$} \\
\hline $\mathrm{PSQ} \rightarrow \mathrm{CS}$ & 0.336 & 0.33 & 0.064 & 0.064 & 5.224 Supported \\
$\mathrm{PPQ} \rightarrow \mathrm{CS}$ & 0.124 & 0.123 & 0.079 & 0.079 & 0.157 Rejected \\
$\mathrm{SA} \rightarrow \mathrm{CS}$ & 0.232 & 0.232 & 0.065 & 0.065 & 3.564 Supported \\
$\mathrm{PP} \rightarrow \mathrm{CS}$ & -0.035 & -0.023 & 0.067 & 0.067 & 0.534 Rejected \\
$\mathrm{TR} \rightarrow \mathrm{CS}$ & 0.135 & 0.139 & 0.072 & 0.072 & 1.878 Supported \\
$\mathrm{CO} \rightarrow \mathrm{CS}$ & 0.287 & 0.287 & 0.081 & 0.081 & 3.567 Supported \\
$\mathrm{CS} \rightarrow \mathrm{RI}$ & 0.651 & 0.652 & 0.051 & 0.051 & 12.697 Supported \\
\hline
\end{tabular}

Source: Processed Data (2014) 
Meanwhile, figure 2. below presents the result of hypotheses testing that is implemented to the model.

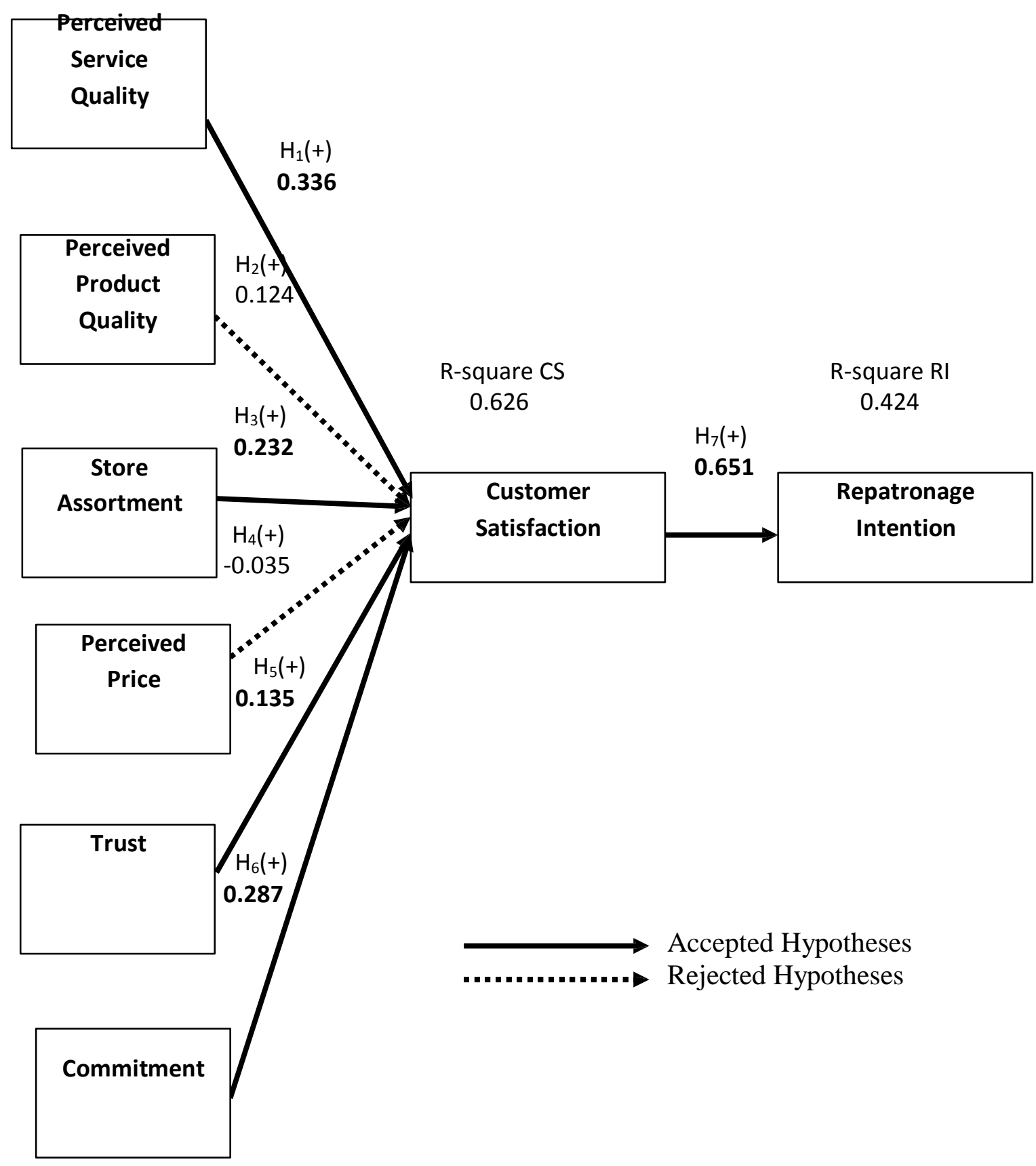

Figure 2. Hypotheses Testing Result

Source: Processed Data

From all seven hypotheses that are proposed in this research, two of these are rejected because of low T-statistics. Low t-statistics indicate low significance level in order to explain the dependent variable. 
Perceived Service Quality has positive original sample and t-statistics (more than 1.64) toward Customer Satisfaction, indicating positive and significant impact of perceived service quality toward customer satisfaction. It is concluded that retailers should give good service quality (through efficiency and hospitality of the employee of retailers) and it can give satisfaction.

Perceived Product Quality has positive original sample toward Customer Satisfaction. However, t-statistics of Perceived Product Quality's value is less than 1.64, indicating insignificance impact. Hypermarkets tend to have broad assortment of products. There are several older goods and fresher goods. Older goods tend to have low quality but fresher goods tend to have better quality. However, it does not significantly impact Customers' Satisfaction.

Store Assortment has positive original sample and t-statistics (more than 1.64) toward customer satisfaction. Therefore, it is shown the significance impact of store assortment toward customer satisfaction. Retailers with good store assortment tend to satisfy customers better, because they provide goods and services at customers' one-stop at that store. Customers can have more time to do other things because they are not making other stops at other stores.

Perceived Price has negative original sample and t-statistics lower than 1.64, indicating negative and insignificance impact to Customer Satisfaction. It can be seen that unfair treatment from employees (Perceived Service Quality) can affect their satisfaction, even though the price of the products are cheap enough.

Trust has positive original sample and t-statistics more than 1.64, indicating positive and significant impact of trust toward customer satisfaction. Trust must be maintained among all parties in the business. If the retailers able to fulfill their promises (being trustable), customers will be satisfied, in which both parties (customers and retailers) can be trustworthy.

Commitment has positive original sample value, indicating positive significance of commitment towards customer satisfaction. Committed customers tend to be satisfied with the retailers. They have certain feeling attachment toward the retailers that automatically bring customer satisfaction.

Customer satisfaction has positive and significant impact toward Repatronage Intentions. This is shown by the positive original sample and high t-statistics (above 1.64), indicating willingness of satisfied customers to return to that store.

\section{MANAGERIAL IMPLICATIONS}

Every retailer wants its customers to have repatronage intention, in which more people will buy products from them. Carrefour and Hypermart in Supermall Karawaci may see the effect of good services and products' quality, then other factors, such as price and other factors to the customers' satisfaction, which may increase repatronage intentions of its customers. If Carrefour and Hypermart has several things that may make people unsatisfied, then it should improve these flaws or weaknesses so more people will be satisfied with Carrefour and Hypermart in Supermall Karawaci. This research also inspires other retailers to pay attention to their own customers and their behaviors towards the retailers' store. They may be satisfied or dissatisfied with the products and services that are offered by the stores. Therefore, they can also improve these flaws. 


\section{CONCLUSION}

There are seven hypotheses that are developed for this research. However, two of these hypotheses are rejected, due to insignificance impact toward customer satisfaction. Both Perceived Product Quality and Perceived Price are considered as least important antecedents of customer satisfaction. However, other factors (Perceived Service Quality, Store Assortment, Trust, and Commitment) are considered as more important antecedents of customer satisfaction. Both Perceived Product Quality and Perceived Price give insignificant impact on customer satisfaction. On the other hand, Perceived Service Quality, Store Assortment, Trust, and Commitment give significant impact on customer satisfaction. Lastly, customer satisfaction has large impact on repatronage intentions that is shown by high significance level. This research's result has several limitations, such as the result cannot cover the whole population, ambiguous questions, failure in giving honest answers, and so on.

For customers, they should express their satisfaction in humane way: complain politely toward the retailers. Retailers should build good trust, by being trust worthy toward the customers. Retailers must make sure that customers receive good service from both Hypermart and Carrefour, and keep the assortments of goods. For the next research, there are many shoppers who shop in both Hypermart and Carrefour. Therefore, other researchers should improve the sample size, so the sample size can cover the whole population.

\section{REFERENCES}

Akbar, Mohammad Muzahid. (2014) A Causal Study on the Antecedents of Retail Shoppers' Repatronage Intention. European Journal of Business and Management 6, no. 4, 9-21.

Chaiyasoonthorn, Wornchanok and Watanyoo Suksa-ngiam. (2011) Factors Influencing Store Patronage: A Study of Modern Retailers in Bangkok Thailand. International Journal of Trade, Economics, and Finance 2, no. 6, 520-525.

Deng, Z., Lu, Y., Wei, K, K. \& Zhang, J. (2010) Understanding Customers Satisfaction and Loyalty: An empirical study of mobile Instant Messages in China. International Journal of Information Management, 30, 289-300.

Hair, Joseph F., Jr., William C. Black, Barry J. Babin, Rolph E. Anderson, \& Ronald L. Tatham. (2006) Multivariative Data Analysis, $6^{\text {th }}$ ed. Upper Saddle River: Pearson Education Inc.

Hair, Joseph F., William C. Black, Barry J. Babin, \& Rolph E. Anderson. (2010) Multivariative Data Analysis: A Global Perspective, $7^{\text {th }}$ ed. Upper Saddle River: Pearson Education Inc.

Hartono, Jogiyanto. (2011) Konsep dan Aplikasi Structural Equation Modelling Berbasis Varian dalam Penelitian Bisnis. Yogyakarta: UPP STIM YKPN.

Hawkins, Del I., \& David L. (2010) Mothersbaugh. Consumer Behavior: Building Marketing Strategy, $11^{\text {th }}$ ed. New York: McGraw-Hills Companies.

Huddleston, Patricia, Judith Whipple, Rachel Nye Mattick and So Jung Lee. (2009) Customer Satisfaction in Food Retailing: Comparing Specialty and 
Conventional Grocery Stores. International Journal of Retailing and Distribution Management 37, no. 1, 63-80.

Kim, Hee-Woong, Yunjie Xu, \& Sumeet Gupta. (2012) Which is more Important in Internet Shopping, Perceived Price or Trust? Journal of Electronic Commerce Research and Applications 11, 241-252.

Lo, Yin-Hsi. (2013) Stakeholder Management in the Chinese Hotel Industry: The Antecedents and Impacts.” International Journal of Contemporary Hospitality Management 25, no. 4, 470-490.

Lovelock, Christopher \& Jochen Wirtz. (2011) Services Marketing: People, Technology, Strategy, $7^{\text {th }}$ ed. Essex: Pearson Education Ltd.

Malhotra, Naresh K. (2007) Marketing Research: An Applied Orientation, $5^{\text {th }}$ ed. Upper Saddle River: Pearson Education Inc.

McDaniel, Carl, Jr. \& Roger Gates. (2010) Marketing Research with SPSS, $8^{\text {th }}$ ed. Singapore: John Wiley \& Sons (Asia) Pte. Ltd.

Merrilees, Bill, Dale Miller, and Carmel Herington. (2013) City Branding: A Facilitating Framework for Stressed Satellite Cities. Journal of Business Research 66, no. 1, 3744.

Schiffman, Leon G. and Leslie Lazar Kanuk. (2007) Consumer Behavior, 9 ${ }^{\text {th }}$ Edition. Upper Saddle River: Pearson Education Inc.

Schiffman, L., Bednall, D., O Cass, A., Paladino, A., Ward, S., Kanuk, L. (2008) Consumer Behaviour. 4th Edition. Pearson Education Australia.

Thurau, Thorsten Hennig. (2004) Customer Orientation of Service Employees: Its Impact on Customer Satisfaction, Commitment, and Retention. International Journal of Service Industry Management 15, no. 5, 460-478.

Tsiotsou, Rodoula. (2006). The Role of Perceived Product Quality and Overall Satisfaction on Purchase Intentions.” International Journal of Consumer Studies 30, no. 2, 207-217.

Wong, Amy and Amrik S. Sohal. (2006) Understanding the Quality of Relationships in Consumer Services: A Study in a Retail Environment. International Journal of Quality and Reliability Management 23, no. 3, 244-264.

Yang, Hao-Wei and Kuei-Feng Chang. (2011) A Comparison of Service Experience on Repatronage Intention between Department Stores amd Hypermarkets in Taiwan. African Journal of Business School 5, no. 19, 7818-7827. 